\title{
フェノール樹脂複合材の摩耗特性に対する金属酸化物の添加効果*
}

\author{
岡山 勝弥 ${ }^{* 1}$, 小林 雅明 $^{* 2}$, 岸本 裕也 ${ }^{* 2}$, 久保田 辰久 ${ }^{* 2}$, 平塚 健一 ${ }^{* 3}$
}

\section{Effect of Metal Oxide Powder on Wear Characteristics of Phenolic Resin Composites}

\author{
Katsuya OKAYAMA ${ }^{* 1}$, Masaaki KOBAYASHI, Hiroya KISHIMOTO, Tatsuhisa KUBOTA \\ and Ken'ichi HIRATSUKA
}

\author{
${ }^{* 1}$ Friction Engineering Dept., ADVICS Co., Ltd. \\ 918-11 Sakashita, Mitsukuri-cho, Toyota-shi, Aichi 470-0424, Japan
}

\begin{abstract}
Brake pads are phenolic resin composites which contain many ingredients such as metal fibers, inorganic fillers, organic fillers, and so on. As a basic study for the improvement of brake pad wear, the influence of fine metal oxide powder on pad wear characteristics was investigated, using pad samples with simplified formulation containing different types of metal oxide. These test samples were rubbed against the cast iron using twin-ring tribometer. Wear test results showed the pad wear varied with the type of metal oxides. Low wear was shown with the addition of metal oxides which were hardly reduced. In other words, pad wear was related to the degree of difficulty in reduction of metal oxide. This indicates the reductive atmosphere was formed at friction interface which was brought by the decomposition of the phenolic resin. Therefore, pad wear depended on the difficulty in reduction of metal oxide in the phenolic resin composites.
\end{abstract}

Key Words : Wear, Tribology, Brake Pad, Composite Material, Metal Oxide, Phenolic Resin, Tribo-Reduction, Mild Wear

\section{1. 緒言}

自動車用ディスクブレーキ(1)に装着されるブレーキパッド(以下, パッド)には, 効き・寿命・NV (Noise Vibration) および強度など，多岐にわたる性能が求められている(2)。これらを同時に満足させる必要があるため，ブレーキ パッドは粉体や繊維など 15〜20 種類の金属・無機材料および有機材料などの様々な原材料を組み合わせ，フェ， 一ル樹脂で成型した複合材となっている(3). それゆえ, 原材料の特性とブレーキ性能とを結び付ける摩擦・摩耗機 構は複雑なものとなり，その機構を十分に説明出来ないことも多い.

また，近年では燃費向上の観点からブレーキ部品の小型・軽量化が検討されており，技術課題のひとつにパッ ドの耐摩耗性の向上が挙げられる，さらに，環境負荷物質の使用制限・撤廃に向けた規制も増加しており，規制 対象となる原材料の代替がパッド開発の大きな課題となっている(4).

これらの課題解決に向けて, パッドとディスクの摩擦面で生じる現象および摩耗機構の解析がますます重要と なる，そこで，著者らはパッドの摩耗機構の解明に主眼を置き，而摩耗性向上の方策を探る基礎検討を進めてい る ${ }^{(5)}$. 既存の而摩耗性向上の手法には, 固体潤滑剤の添加やパッド母材の強度向上などが挙げられるが, これら は大幅な効きの低下や NV 特性の悪化を招くなどの背反性能が明らかになっており, 新たな手法に期待が寄せら れている.

そこで，トライボロジー分野の摩耗に関する研究に目を向けると，平塚らはピン・オン・ディスクにおける銅 $(\mathrm{Cu})$ と鉄 $(\mathrm{Fe})$ の摩擦において, 低摩耗のマイルド摩耗の発現には摩耗粉に含まれる微細な $\mathrm{Fe}_{2} \mathrm{O}_{3}$ が関与する

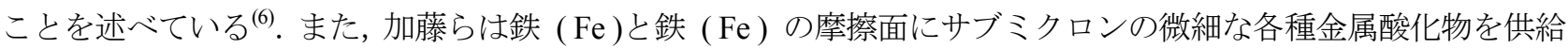

\footnotetext{
* 原稿受付 2012 年 3 月 7 日

*1 正員，(株)アドヴィックス フリクション技術部（テ470-0424 愛知県豊田市御作町坂下 918-11）

*2 (株) アドヴィックス フリクション技術部

*3 正員, 千葉工業大学大学院 工学研究科（干275-0016 千葉県習志野市津田沼 2-17-1）

E-mail: katsuya_okayama@nts.advics.co.jp
} 
した場合, 焼結されや寸い金属酸化物ではマイルド摩耗が生じることを明らかにしている(7).これらの研究から, 摩擦面に微細な金属酸化物が存在すると低摩耗状態をもたらすと解釈できる.つまり，パッドに対しても微細な 金属酸化物を添加することによって耐摩耗性の向上が期待できる.これまでにも金属酸化物はパッドの原材料と して用いられているが，通常はディスク材を研削するアブレシブ材として摩擦係数を調整する目的で使用される ${ }^{(8)}$. このため, 金属酸化物の粒径が微細であると研削力が得られないことから，一般には $10 \mu \mathrm{m}$ 以上の粗い粒径のも のが用いられる，それゆえ，而摩耗性向上を目的としてパッドへの微細な金属酸化物の添加効果を調べた研究は ほとんどない，また，パッドのトライボロジ一特性向上を目的とした各種原材料の添加効果を調べた取り組み(9) もみられるが，前述と同様に微細な金属酸化物の添加効果を調べた研究は見当たらない.

以上の背景から, 本論文では新たな着眼点としてサブミクロンから $1 \mu \mathrm{m}$ 程度の微細な金属酸化物を取り上げ, パッドの耐摩耗性向上に対する添加効果および摩耗機構の解明を行った. その結果, 添加した金属酸化物の種類 によって摩耗量が変化すること, またパッド材摩耗量は添加した金属酸化物の還元のされやすさ, および還元に よって生成された金属とディスク材の金属との凝着性によって説明できることを示した．さらに，金属酸化物の 還元はパッドに含まれるフェノール樹脂の分解が関与していることを突き止め, パッド材の摩耗過程に新たな機 構を付与することができたので報告する.

\section{2. 試料の製作および実験方法}

\section{$2 \cdot 1$ 試料の製作}

本論文では摩耗機構の解析を単純化するため, 通常のパッドの組成を簡素化した試料を用いた，試料にはパッ ドを構成するために必要なフェノール樹脂，アラミド繊維，硫酸バリウム，水酸化カルシウムの 4 種類に，本論 文の検討対象である金属酸化物を 1 種類加えた計 5 種類の原材料を用いた. 原材料の配合量を表 1 に示寸.また, 金属酸化物には，平均粒径がサブミクロンから $1 \mu \mathrm{m}$ 程度の微細な粒径のものを 8 種類準備した. 本論文で用い た金属酸化物を表 2 に示寸.これらの原材料をミキサーで均一に混合し, 金型に投入した後, $160^{\circ} \mathrm{C}$ に 5 分間の 熱成型を行った. 次に, 得られた成型品を $210^{\circ} \mathrm{C} \cdot 3$ 時間で熱処理を行い, その後, 外径 $30 \mathrm{~mm}$, 厚み $5 \mathrm{~mm}$ に機 械加工し，パッド材を製作した。 また，金属酸化物の添加効果を明らかにするため，金属酸化物を添加しないパ ッド材（表 1 における金属酸化物を硫酸バリウムにて置換）も比較材として製作した．なお，ディスク材には乗 用車に装着されている鋳鉄（FC200，モース硬度： $4.5^{(10)}$ ) ディスクから外径 $30 \mathrm{~mm}$ ，厚み $2 \mathrm{~mm}$ の試験片を切り 出し，ディスク材として準備した。 それぞれの試料の外観を図 1 に示す.

Table 1 Formulation of test samples

\begin{tabular}{c|c|c}
\hline Ingredient & Chemical formula & Content [Vol. \%] \\
\hline \hline Phenolic resin & $-\left(\mathrm{C}_{6} \mathrm{H}_{4}-\mathrm{OH}-\mathrm{CH}_{2}\right)_{\mathrm{n}}-$ & 20 \\
\hline Aramid fiber & $-\left(\mathrm{NH}-\mathrm{C}_{6} \mathrm{H}_{4}-\mathrm{NH}-\mathrm{CO}-\mathrm{C}_{6} \mathrm{H}_{4}-\mathrm{CO}\right)_{\mathrm{n}}-$ & 10 \\
\hline Barium sulfate & $\mathrm{BaSO}_{4}$ & 63 \\
\hline Calcium hydroxide & $\mathrm{Ca}(\mathrm{OH})_{2}$ & 2 \\
\hline Metal oxide & $\mathrm{Table} 2$ & 5 \\
\hline \hline \multicolumn{2}{c|}{} & 100 \\
\hline
\end{tabular}

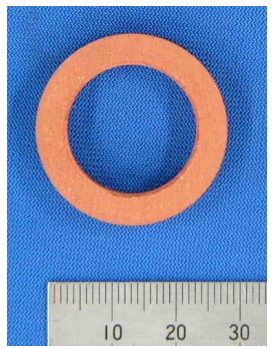

(a) Pad material

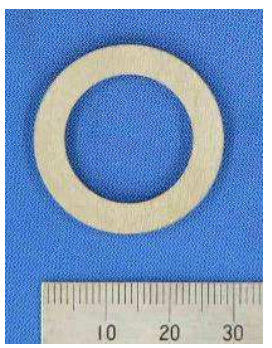

(b) Disk material

Fig. 1 Test sample images

Table 2 Metal oxides as a pad additive

\begin{tabular}{c|c|c|c|c|c|c|c|c}
\hline Pad material & $(1)$ & $(2)$ & $(3)$ & $(4)$ & (5) & (6) & (7) & 8 \\
\hline \hline Metal oxide & $\mathrm{CeO}_{2}$ & $\mathrm{MgO}$ & $\mathrm{TiO}_{2}$ & $\begin{array}{c}\mathrm{Fe}_{2} \mathrm{O}_{3} \\
(\alpha \text {-type })\end{array}$ & $\mathrm{Fe}_{3} \mathrm{O}_{4}$ & $\mathrm{SnO}_{2}$ & $\mathrm{Bi}_{2} \mathrm{O}_{3}$ & $\mathrm{CuO}^{2}$ \\
\hline Median diameter $[\mu \mathrm{m}]$ & 0.52 & 0.32 & 0.96 & 0.30 & 0.30 & 1.3 & 1.6 & 0.92 \\
\hline Mohs hardness [- ] & $6.0^{(11)}$ & $6.5^{(11)}$ & $\begin{array}{c}6.0 \sim \\
6.5^{(12)}\end{array}$ & $\begin{array}{c}5.0 \sim \\
6.0^{(12)}\end{array}$ & $\begin{array}{c}5.5 \sim \\
6.5^{(12)}\end{array}$ & $\begin{array}{c}6.0 \sim \\
6.5^{(12)}\end{array}$ & $4.5^{(13)}$ & $3.5^{(13)}$ \\
\hline
\end{tabular}




\section{$2 \cdot 2$ 実験方法}

摩耗試験に用いたツィンリング試験機 ${ }^{(14)}$ の全体を図 2 (a) に示す. $2 \cdot 1$ で製作した試料を図 2 (b) のように取り 付け，ディスク材にパッド材を $10 \mathrm{~N}$ で押し付けて両試料を同回転方向・同回転速度で回転させ，接触界面に相対 摺動速度 $400 \mathrm{~mm} / \mathrm{s}$ のすべり摩擦を生じさせた．これは，実際の車両が国内市街地で走行する際によく使用される 制動条件から設定した值である，ただし，ツインリング試験機では，試験片の外径および回転数の制限から，実 際の制動条件に比へ摺動速度が約 1/5 1/10 程度になっている.このため, 押し付け荷重を高く設定し, 試験負 荷としての PV 值（P : 荷重，V：摺動速度）を実際の制動条件に合わせた。また，試験片温度は国内市街地でよ く使用されるブレーキ温度の $100^{\circ} \mathrm{C}$ に設定した．実験条件の詳細を表 3 に示寸．なお，パッド材およびディスク 材の摩耗量は, 試験前後の試料片の質量変化から算出した。また, 摩耗機構解明のため, 試験後の摩擦面および 試験時に回収した摩耗粉を電界放射型走查電子顕微鏡（FE-SEM）を用いて観察した.

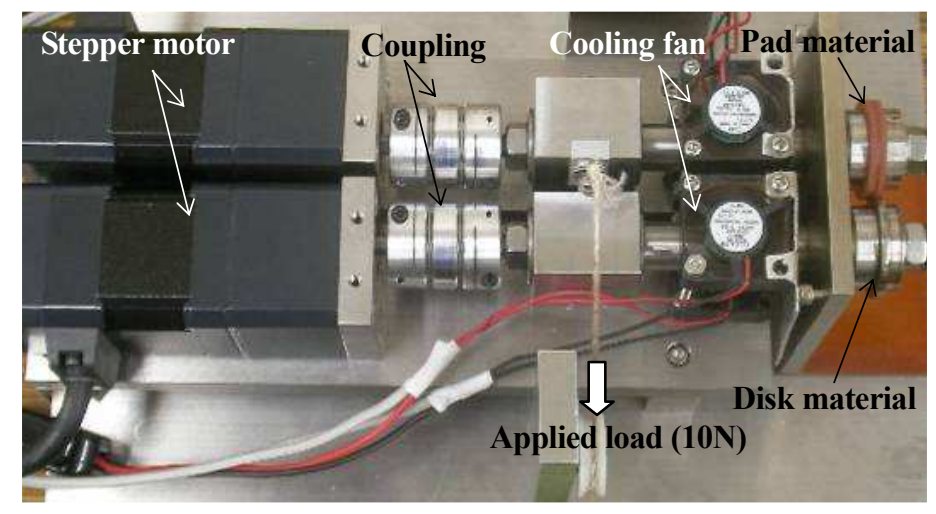

(a) Schematic of twin-ring tribometer

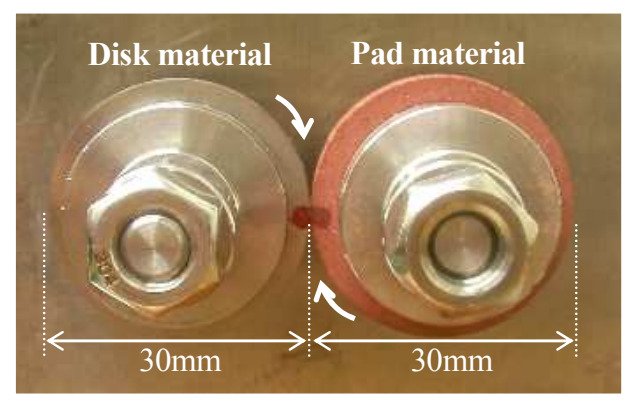

(b) Set-up of test samples

Fig. 2 Test apparatus

Table 3 Wear test conditions

\begin{tabular}{c|c|c}
\hline \multirow{2}{*}{ Pad } & Material & $\begin{array}{l}\text { (1), (2), (3), (4), (5), (6), (7), (8), } \\
\text { Reference ( without metal oxide ) }\end{array}$ \\
\cline { 2 - 3 } & Size $[\mathrm{mm}]$ & $\phi 30 \times 5^{\mathrm{t}}$ \\
\hline \multirow{2}{*}{ Disk } & Material & Cast iron ( FC200 ) \\
\cline { 2 - 3 } & Size $[\mathrm{mm}]$ & $\phi 30 \times 2^{\mathrm{t}}$ \\
\hline \multicolumn{2}{|c}{ Specimen temperature $\left[{ }^{\circ} \mathrm{C}\right]$} & 100 \\
\hline \multicolumn{2}{|c}{ Applied load $[\mathrm{N}]$} & 10 \\
\hline \multicolumn{2}{|c}{ Sliding velocity $[\mathrm{mm} / \mathrm{s}]$} & 400 \\
\hline \multicolumn{2}{|c}{ Sliding distance $[\mathrm{km}]$} & 100 \\
\hline
\end{tabular}

\section{3. 実験結果}

\section{$3 \cdot 1$ 摩耗試験結果}

摩耗試験の結果を図 3 に示す. 添加した金属酸化物の種類によってパッド材の摩耗量が異なることが確認され る. パッド材の摩耗量は添加した金属酸化物の種類によって二つに大別でき, $\mathrm{CeO}_{2}, \mathrm{MgO}, \mathrm{TiO}_{2}, \mathrm{Fe}_{2} \mathrm{O}_{3}$ を添加 したパッド材の摩耗量は金属酸化物を添加していない比較材（Reference）よりも少なくなり，逆に $\mathrm{Fe}_{3} \mathrm{O}_{4}, \mathrm{SnO}_{2}$, $\mathrm{Bi}_{2} \mathrm{O}_{3}, \mathrm{CuO}$ を添加したパッド材の摩耗量は比較材よりも多くなった. 特に $\mathrm{Fe}_{3} \mathrm{O}_{4}$ を添加したパッド材の摩耗量が 多くなっている．また， $\mathrm{Fe}_{2} \mathrm{O}_{3}$ と $\mathrm{Fe}_{3} \mathrm{O}_{4}$ は，同じ $\mathrm{Fe}$ の酸化物であるが摩耗量に大きな差が見られた.

以上の結果から，本論文では金属酸化物の種類による摩耗特性の違いに着目し，摩耗機構の解析を進めた。 な お，ディスク材の摩耗量については，3·4 で示すように摩擦面に付着物がみられ，また付着物の量は各パッド材 によって異なることから正確な摩耗量の算出が困難であり, 本論文では議論から除外した。 


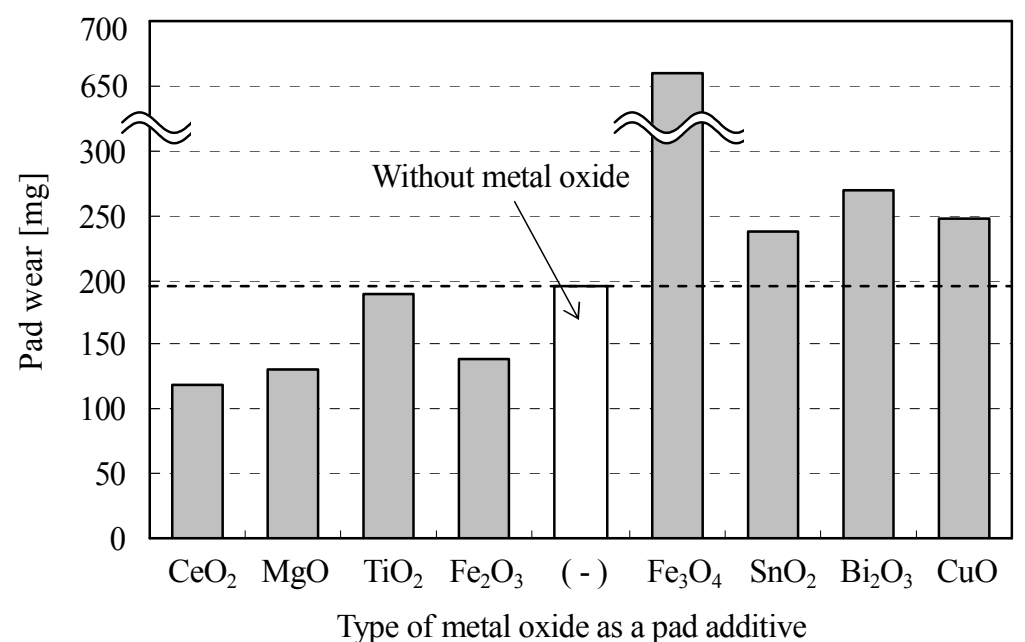

Fig. 3 Relationship between pad wear and each metal oxide as a pad additive

\section{$3 \cdot 2$ パッド材の摩擦面の状態}

図 4 はパッド材摩擦面の観察画像である. 摩擦面には燐片状の組織が多く観察され, これらは図 5 に示寸摩擦 前のパッド材の組織と比べて形態が大きく異なっていることから，摩擦によって形成されたものとわかる.この 燐片状組織を詳しく観察するとその状態に違いがみられ, 次の二つに大別できることがわかった.一つは, $\mathrm{CeO}_{2}$, $\mathrm{MgO}, \mathrm{TiO}_{2}, \mathrm{Fe}_{2} \mathrm{O}_{3}$ を添加したパッド材で観察され, 図 6 (a) のように端部も含めて全体的に平滑で緻密な組織で ある. もう一つは, $\mathrm{Fe}_{3} \mathrm{O}_{4}, \mathrm{SnO}_{2}, \mathrm{Bi}_{2} \mathrm{O}_{3}, \mathrm{CuO}$ を添加したパッド材で観察され, 図 6 (b) のように端部には粒子 が凝集した状態の粗い組織である.この組織の違いはパッド材の摩耗量との関係があり, 摩耗が少ないパッド材 では平滑で緻密な組織が形成されている.

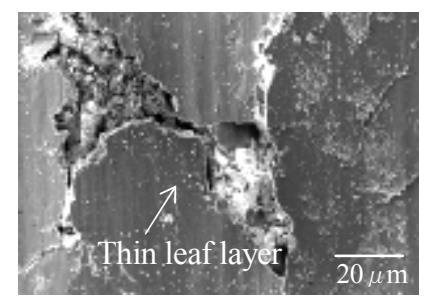

(a) $\mathrm{CeO}_{2}$

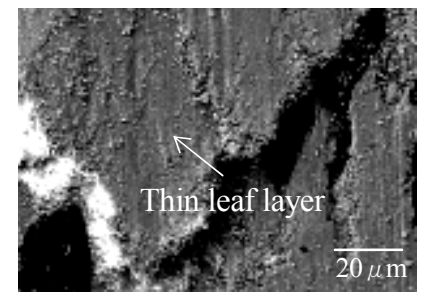

(e) $\mathrm{Fe}_{3} \mathrm{O}_{4}$

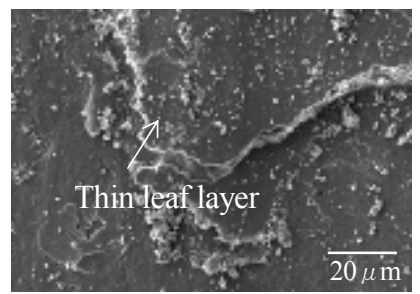

(b) $\mathrm{MgO}$

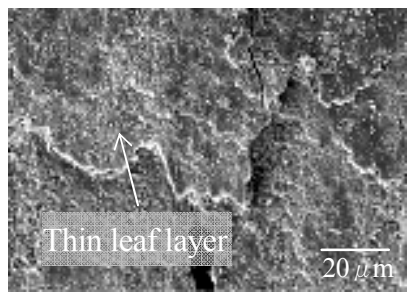

(f) $\mathrm{SnO}_{2}$

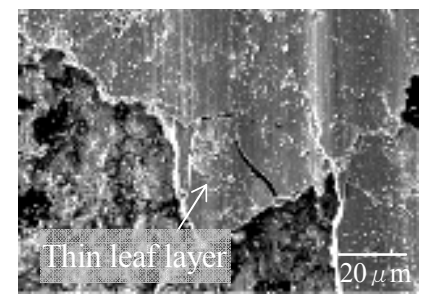

(c) $\mathrm{TiO}_{2}$

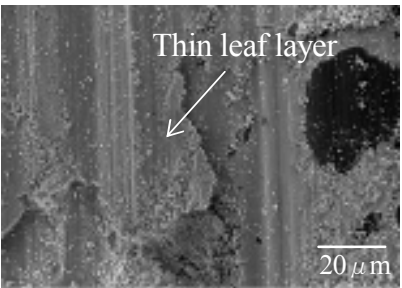

(g) $\mathrm{Bi}_{2} \mathrm{O}_{3}$

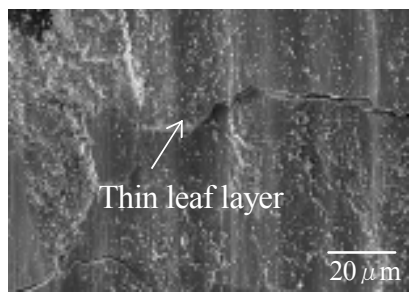

(d) $\mathrm{Fe}_{2} \mathrm{O}_{3}$

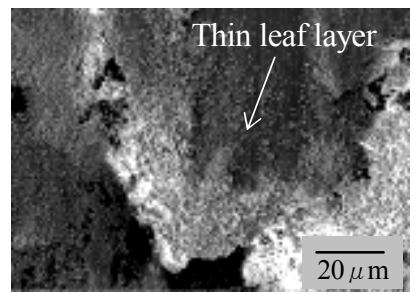

(h) $\mathrm{CuO}$

Fig. 4 SEM micrographs of worn surfaces of pad materials containing each metal oxide

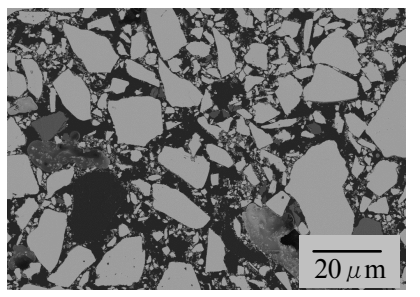

Fig. 5 SEM micrograph of pad structure as prepared

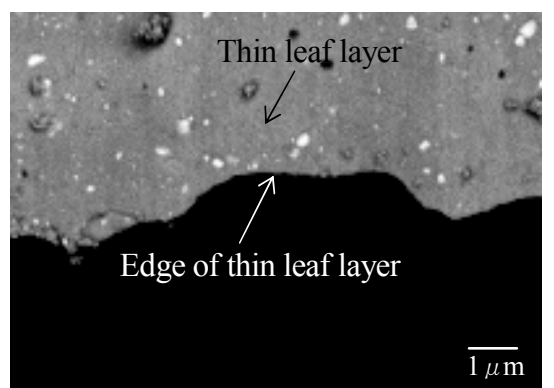

(a) $\mathrm{CeO}_{2}$

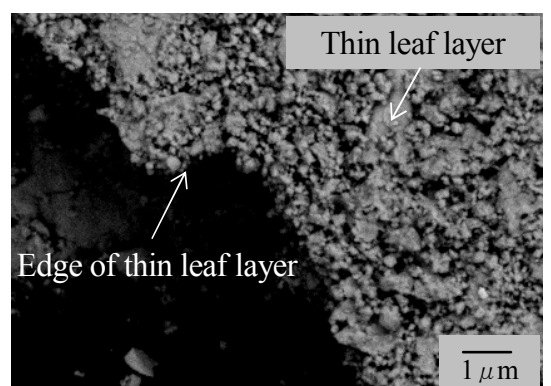

(b) $\mathrm{CuO}$

Fig. 6 Enlarged view of thin leaf layer 


\section{$3 \cdot 3$ 被膜層の構造}

パッド材の摩擦面に形成された粼片状組織をさらに詳しく調べるため, 摩耗量が少なかった $\mathrm{CeO}_{2}$ を添加した パッド材と摩耗量が多かった $\mathrm{CuO}$ を添加したパッド材を切断し, 樹脂に封埋処理した後, 精密研磨を行い摩擦面 の断面観察を行った．なお，研磨によるダメージから燐片状組織を保護するため，最表面に厚さ約 $0.1 \mu \mathrm{m} の$ 金 属コーティングを施した.

観察画像を図 7 に示す．画像の下側にはパッド材の組織が観察され，配合した原材料の形状をみることができ る. 両パッド材表面には，ともにパッド材の組織とは異なる $5 \sim 10 \mu \mathrm{m}$ 程度の厚みをもった組織が形成されてい ることがわかった。この組織はパッド母材を被うような形態であることから，本論文ではこれを被膜層とよぶこ とにする．なお，被膜層とパッド材の間には隙間が見られるが，これは封埋処理時に被膜層がパッド材から剥が れたためである．被膜層を拡大して観察すると，パッド材側には微細な粒子や気孔が存在し，また摩擦面の最表 面には $0.1 \sim 1 \mu \mathrm{m}$ 程度の厚みの緻密な組織が存在する.このことから被膜層は, 摩擦面で形成された微細な摩 耗粉が凝集・堆積し, ディスク材と摩擦する最表面近傍で組織が緻密化していることがわかった.また, CuO を 添加したパッド材と比較すると, $\mathrm{CeO}_{2}$ を添加したパッド材の被膜層は端部を含めて組織が緻密であり, 前項の図 6 で見られた摩擦面観察結果の傾向とも一致する.

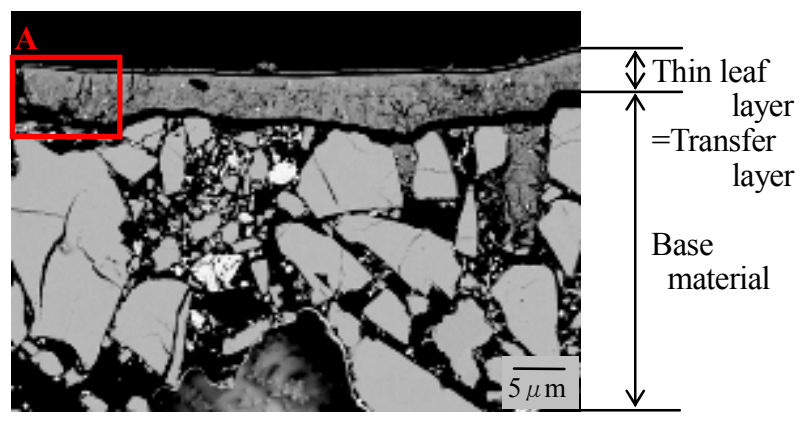

(a) $\mathrm{CeO}_{2}$

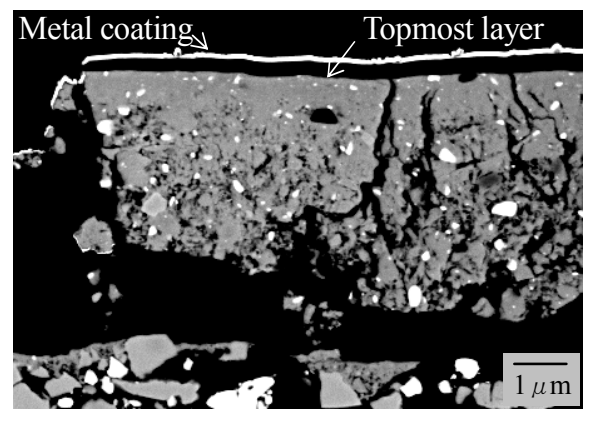

(c) Enlarged view of area A

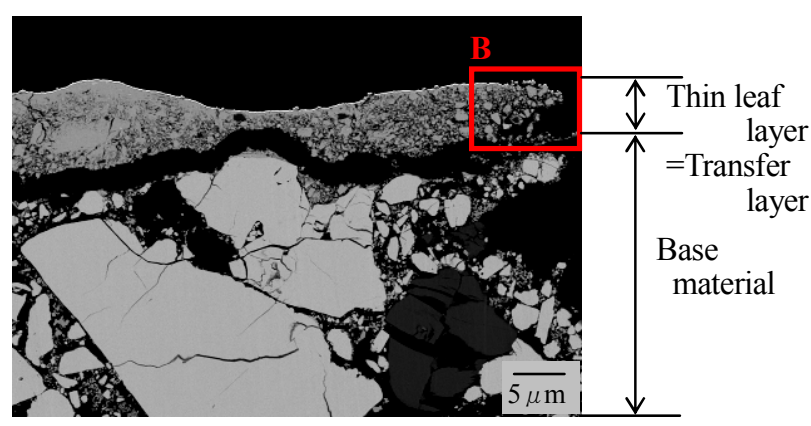

(b) $\mathrm{CuO}$

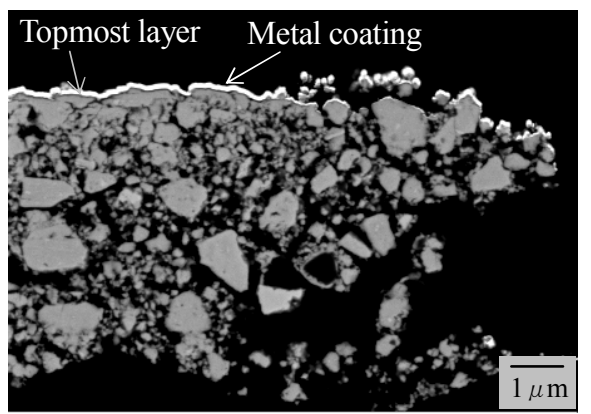

(d) Enlarged view of area B

Fig. 7 Cross-sectional view of worn surfaces of pad materials containing $\mathrm{CeO}_{2}$ and $\mathrm{CuO}$

\section{$3 \cdot 4$ ディスク材の摩擦面の状態}

ディスク材摩擦面の観察画像を図 8 に示寸.ディスク材の摩擦面には, 黒色部が多く観察されるのが特徴である. この黒色部を拡大寸ると図 9 のように粒状物が凝集した状態となっている. これは摩擦面で生成された微細な摩耗 粉が凝集して，それがディスク材に移着したものと推定できる．また，この移着物の量はパッド材に添加した金属 酸化物の種類によって異なっており, $\mathrm{CeO}_{2}, \mathrm{MgO}, \mathrm{TiO}_{2}, \mathrm{Fe}_{2} \mathrm{O}_{3}$ を添加したパッド材では移着物が少なく, $\mathrm{Fe}_{3} \mathrm{O}_{4}$, $\mathrm{SnO}_{2}, \mathrm{Bi}_{2} \mathrm{O}_{3}, \mathrm{CuO}$ を添加したパッド材では移着物が多い. すなわち, 移着物の量はパッド材の摩耗量と関係があり, 移着物が少ないパッド材では摩耗量が少なく, 逆に移着物が多いパッド材では摩耗量が多くなる傾向がみられる. 


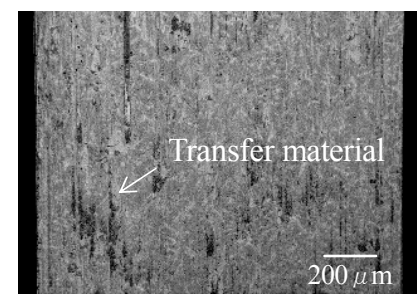

(a) $\mathrm{CeO}_{2}$

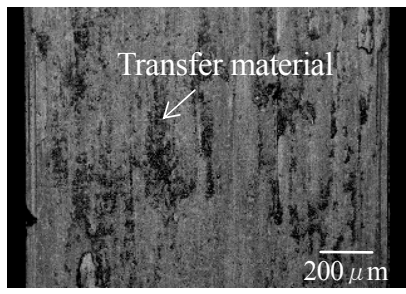

(e) $\mathrm{Fe}_{3} \mathrm{O}_{4}$

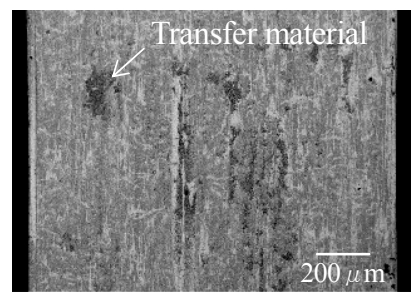

(b) $\mathrm{MgO}$

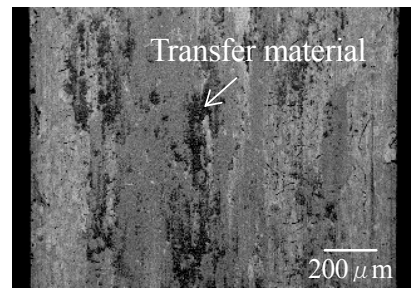

(f) $\mathrm{SnO}_{2}$

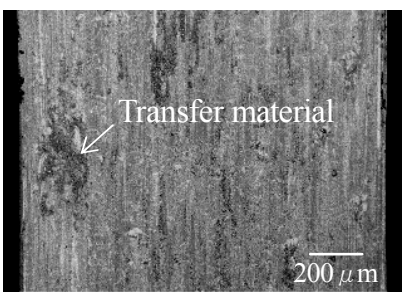

(c) $\mathrm{TiO}_{2}$

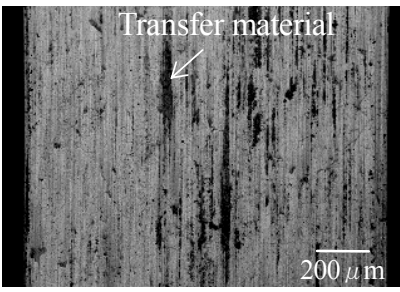

(g) $\mathrm{Bi}_{2} \mathrm{O}_{3}$

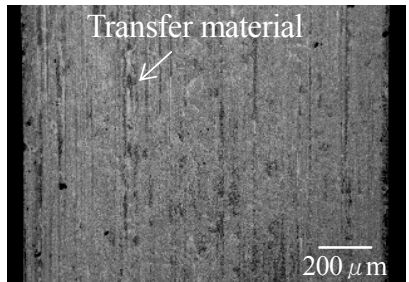

(d) $\mathrm{Fe}_{2} \mathrm{O}_{3}$

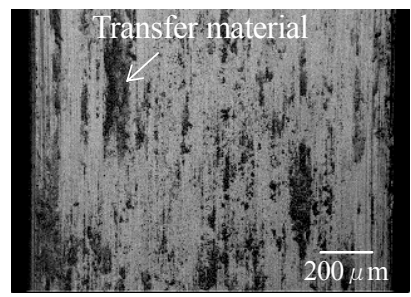

(h) $\mathrm{CuO}$

Fig. 8 SEM micrographs of worn surfaces of disk samples

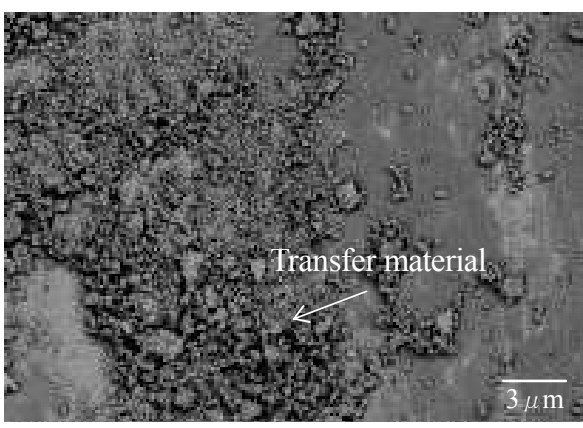

(a) $\mathrm{CeO}_{2}$

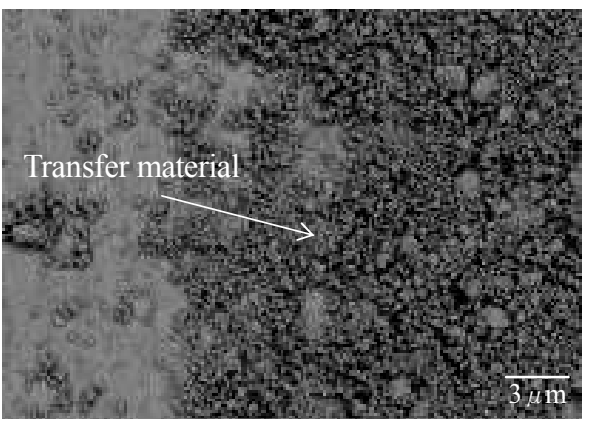

(b) $\mathrm{CuO}$

Fig. 9 Enlarged view of transfer material on disk surface

また，図 9 において移着物以外の部分に着目すると，ディスク材よりも高硬度の $\mathrm{CeO}_{2}$ を添加したパッド材およ び低硬度の $\mathrm{CuO}$ を添加したパッド材のいずれにおいても, アブレシブ摩擦にみられる粒径に応じた擦過痕がディ スク材には認められないことがわかる.

\section{$3 \cdot 5$ 摩耗粉の状態}

試験時に回収した摩耗粉の観察画像を図 10 に示す.これらの画像から摩耗粉の大きさは $50 \sim 200 \mu \mathrm{m}$ 程度の 粗大な粒子から $1 \mu \mathrm{m}$ 以下の微細な粉末にまで広く分布していることがわかる．また，パッド材に添加した金属 酸化物の種類によって摩耗粉の状態に違いがみられた. $\mathrm{CeO}_{2}, \mathrm{MgO}, \mathrm{TiO}_{2}, \mathrm{Fe}_{2} \mathrm{O}_{3}$ を添加したパッド材では摩耗 粉中の粗大摩耗粉の割合が少なく, 逆に $\mathrm{Fe}_{3} \mathrm{O}_{4}, \mathrm{SnO}_{2}, \mathrm{Bi}_{2} \mathrm{O}_{3}, \mathrm{CuO}$ を添加した場合ではその割合が多い.

図 11 に粗大摩耗粉を拡大した画像を示寸. 粗大摩耗粉には図 11 (a) のような燐片状のものが多くみられ，拡 大寸ると平滑な部分と微細な粒子が凝集した部分とが観察される（図 11 (b))。これは $3 \cdot 3$ で観察した被膜層の組 織と特徵が一致していることから, 被膜層の一部が剥がれ落ち摩擦面外に排出されたものが粗大摩耗粉として観 察されたと考えられる．また，パッド材の摩耗量との関係には，摩耗量が多い試料で粗大摩耗粉の割合が多くな る傾向がみられた。 


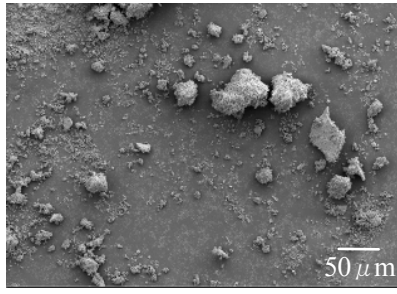

(a) $\mathrm{CeO}_{2}$

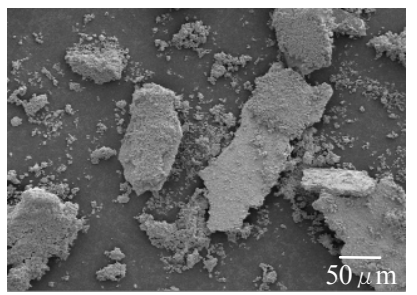

(e) $\mathrm{Fe}_{3} \mathrm{O}_{4}$

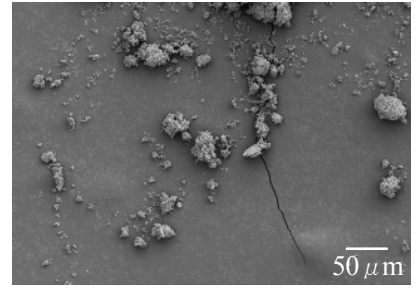

(b) $\mathrm{MgO}$

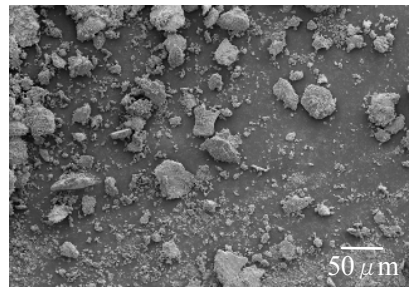

(f) $\mathrm{SnO}_{2}$

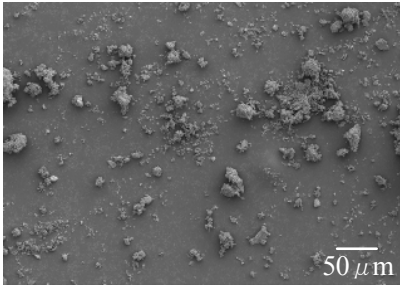

(c) $\mathrm{TiO}_{2}$

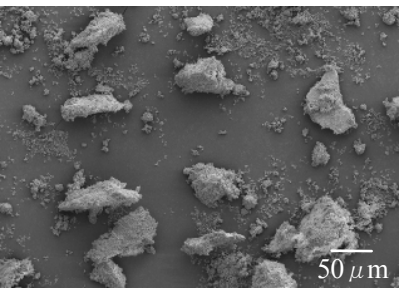

(g) $\mathrm{Bi}_{2} \mathrm{O}_{3}$

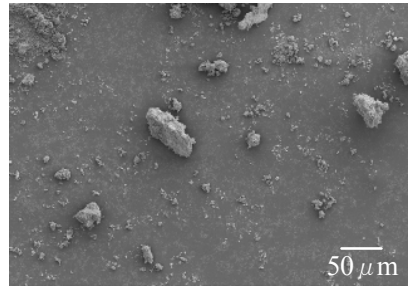

(d) $\mathrm{Fe}_{2} \mathrm{O}_{3}$

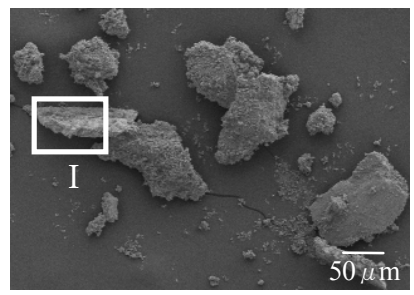

(h) $\mathrm{CuO}$

Fig. 10 SEM micrographs of wear debris

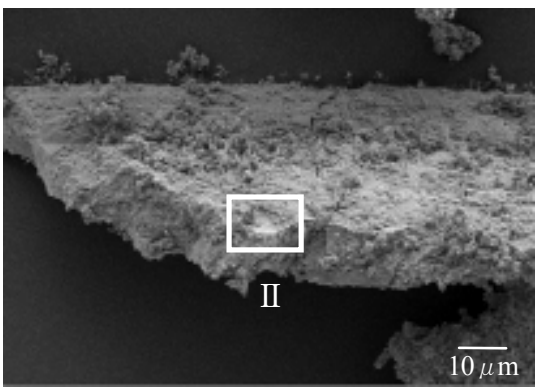

(a) Enlarged view of area I in Fig.10

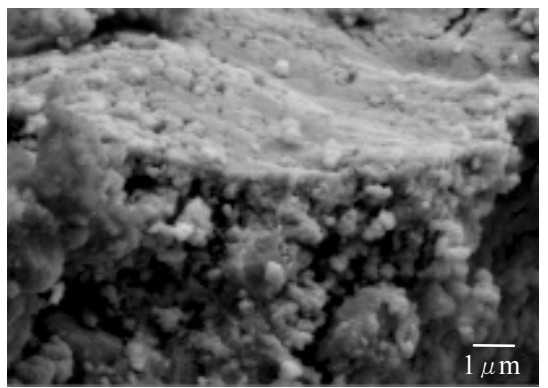

(b) Enlarged view of area II

Fig. 11 SEM micrographs of coarse wear debris (Metal oxide : $\mathrm{CuO}$ )

\section{4. 摩耗機構の考察}

\section{$4 \cdot 1$ 被膜層の挙動}

パッド材，ディスク材の摩擦面および摩耗粉の観察結果から，パッド材の摩耗機構を次のように説明できる. まず，パッド材とディスク材の真実接触部で剪断破壊が生じ, 微細な摩耗粉が生成される. 生成された微細な摩耗 粉は, 摩擦面で圧縮・剪断力を繰り返し受けることによって摩耗粉同士が凝集し, 固結することでパッド材の摩擦 面に被膜層を形成する，その際，ディスク材への凝着性が高いと被膜層の一部がディスク材に移着し，パッド材表 面から脱落して摩擦面外に排出されやすくなる (図 12).これが摩耗量の多くなる摩耗機構である. また, 被膜層 が脱落して摩擦面外に排出されやすいと, 微細な摩耗粉が固結するために必要な圧縮・剪断力を十分に受けられず, 被膜層の緻密化が妨げられる.つまり, $\mathrm{Fe}_{3} \mathrm{O}_{4}, \mathrm{SnO}_{2}, \mathrm{Bi}_{2} \mathrm{O}_{3}, \mathrm{CuO}$ を添加したパッド材で観察されたように, 粒状 物を多く含んだ粗い組織の被膜層となる。一方, ディスク材への凝着性が低いと，摩擦面外一の被膜層の排出が抑 制され摩耗が低減される。このとき, 被膜層は摩擦面で滞留しや寸くなるため, 微細な摩耗粉の固結が進み被膜層 が緻密化する。つまり， $\mathrm{CeO}_{2}, \mathrm{MgO}, \mathrm{TiO}_{2}, \mathrm{Fe}_{2} \mathrm{O}_{3}$ を添加したパッド材で観察されたように緻密な被膜層が形成され る. なお，被膜層の緻密化については，摩耗粉同士の固結されやすさも考慮する必要がある，一般に，粉体が固結す る場合には，その粒径が影響することが知られており ${ }^{(15)}$, 本論文においてもパッド材に添加した金属酸化物の粒径の 影響について検討した. しかしながら, 平均粒径が同じ $\mathrm{Fe}_{2} \mathrm{O}_{3}$ と $\mathrm{Fe}_{3} \mathrm{O}_{4}$ を比較しても, 図 4 のパッド材の被膜層の緻密 さには違いが認められる. さらに，ほぼ同一の平均粒径である $\mathrm{TiO}_{2}$ と $\mathrm{CuO}$ を比較しても, 被膜層の緻密さに違いが 認められた.つまり, 被膜層の緻密化に対しては添加した金属酸化物の粒径の影響は小さいと考えられる.

また，ディスク材を拡大観察した図 9 において，添加した金属酸化物の粒径に応じた擦過痕はディスク材から観察 されていない，すなわち，本論文の摩耗過程では添加した金属酸化物はアブレシブ材としての研削作用は小さく, 金 


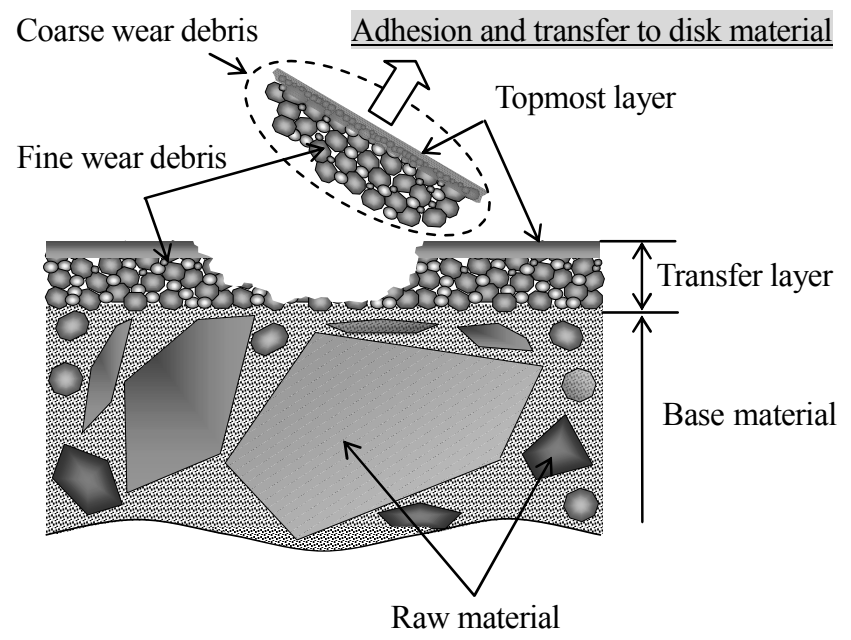

Fig. 12 Wear model of pad material

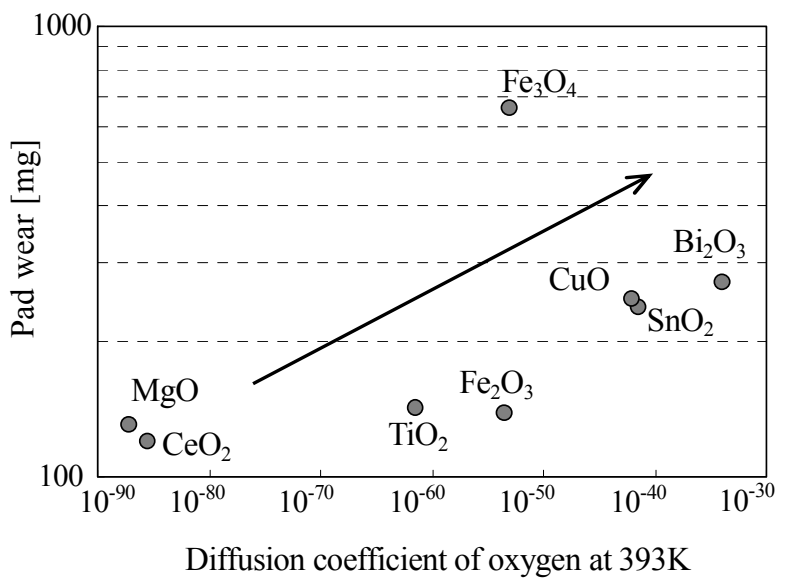

Fig. 13 Relationship between pad wear and diffusion coefficient of oxygen

属酸化物の硬度が摩耗特性に及ぼす影響は小さいことがわかる.この一因には用いた金属酸化物の粒径が微細である ことが考えられる.

以上のことから，ディスク材に対する被膜層の凝着性，ならびにその凝着性は添加した金属酸化物の種類によ って変化することが, パッド材の摩耗機構の本質であると結論づけられる.

金属同士の摩擦においては，摩擦面に供給した金属酸化物が摩擦面で焼結されることによってトライボフィル ムが形成され，摩耗が低減される機構を加藤らが報告している(7).さらに，トライボフィルムの形成には金属酸 化物の酸素拡散係数が影響することについても言及している. 本論文で観察されたパッド材の被膜層は, このト ライボフィルムの一つと捉えることもでき，金属同士の摩擦時と同じ摩耗機構が存在するかについて検討した. その結果を図 13 に示寸. 加藤らの研究では, 酸素拡散係数に対して摩耗量は負の相関がみられる(7)のに対し, 本 論文の実験結果は概ね正の相関がみられ，傾向が一致しないことがわかる．つまり，パッド材とディスク材の摩 擦では，金属同士を摩擦させた場合とは異なる摩耗機構が存在するといえる.

\section{$4 \cdot 2$ 金属酸化物の還元による摩耗増大機構の提唱}

添加した金属酸化物の種類の違いが, ディスク材に対する被膜層の凝着性を変化させる機構を $4 \cdot 1$ で考察した. 一般に，凝着性は金属と金属で高く，金属と金属酸化物などの非金属とでは低いことが知られている(16). 本論文 ではディスク材に金属である鋳鉄を用いており，パッド材に添加した金属酸化物の違いが凝着性に大きな違いを 生じさせたとは考えにくい，そこで，パッド材に添加した金属酸化物がディスク材と接する被膜層の最表面で還 元されて金属に変化すること, それが被膜層の凝着性に大きな違いを生じさせる要因と考えた. すなわち, 還元 されやすい金属酸化物は，摩擦時に被膜層の最表面で還元されて金属となり，ディスク材との間で強い凝着が生 じる. 反対に，還元されにくい金属酸化物では摩擦時に被膜層最表面で金属が生成されにくいため，ディスク材 との強い凝着は生じない.これが摩耗量に差が生じる機構である.

本論文ではこれらの仮説の検証を行うため, まず摩擦時に金属酸化物が還元される要因を検討した. これまで の金属と金属の摩擦におけるマイルド摩耗の研究と比べ, 本論文で扱うパッド材には有機物のフェノール樹脂が 多く含まれていることが大きく異なる点である. フェノール樹脂については, 摩擦時の熱や剪断力による分解につ いて調查した研究がある ${ }^{(17)}$ が，著者らはこのフェノール樹脂の分解が金属酸化物の還元に関与していると考えた. 金属酸化物の還元については，鉄鉱石の精錬時にみられるようなコークスによる酸化鉄の還元などが一般的に知ら れている(18)が，フェノール樹脂の分解が金属酸化物を還元することを示した研究例は見当たらない，そこで，本論 文では熱重量測定装置を用いた実験方法を検討し，検証を行った。

検証にはフェノール樹脂と金属酸化物を混合した試料を加熱し,フェノール樹脂が分解した時の金属酸化物の変 化を調べた. 試料は, (1)フェノール樹脂, (2) $\mathrm{Fe}_{2} \mathrm{O}_{3}$ ( $\alpha$-type), (3)フェノール樹脂と $\mathrm{Fe}_{2} \mathrm{O}_{3}$ ( $\alpha$-type) の混合物の 3 種 類を準備した. $\mathrm{Fe}_{2} \mathrm{O}_{3}\left(\alpha\right.$-type)を用いた理由は, 組成変化によって色および磁性が変化する ${ }^{(19)}$ 特徵があり, その場で 
Table 4 Test conditions of heating tests

\begin{tabular}{|c|c|}
\hline Sample & 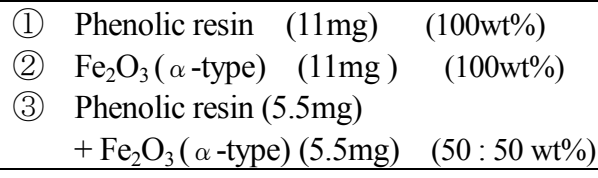 \\
\hline Temperature & R.T. $\sim 800{ }^{\circ} \mathrm{C}$ \\
\hline Gas Purge & $\mathrm{N}_{2}(80 \mathrm{ml} / \mathrm{min})$. \\
\hline
\end{tabular}

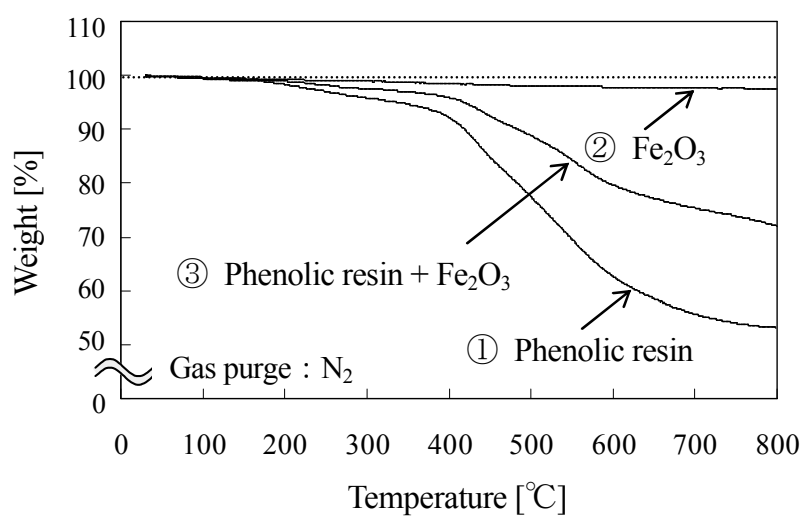

Fig.14 Relationship between sample weight and temperature

還元の有無を捉えやすいためである. また，フェノール樹脂は $210^{\circ} \mathrm{C} て ゙ 3$ 時間の硬化処理を行い，乳鉢で細かく粉 砕したものを用いた．実験装置には熱重量測定装置（森島津製作所製 DTA50）を用い，また金属酸化物が還元さ れて金属が生じた場合に, その金属が酸化されて再び金属酸化物となることを抑制するため, 窒素ガスを $80 \mathrm{ml} / \mathrm{min}$. でパージした. 実験条件を表 4 に示寸. また, 加熱前後の試料を光学顕微鏡で観察するとともに, 磁石への付着有 無によって磁性の変化を調べた.

図 14 は加熱時の各試料の重量変化を示したものである. フェノール樹脂のみの試料では, $400 \sim 600^{\circ} \mathrm{C} て ゙$ 重量が 大きく減少し，この温度範囲でフェノール樹脂が分解していることが確認できる．また， $\mathrm{Fe}_{2} \mathrm{O}_{3}$ のみの試料では ほとんど重量は変化しないが，フェノール樹脂と $\mathrm{Fe}_{2} \mathrm{O}_{3}$ を混合した試料ではフェノール樹脂含有分に見合う減重 量が確認される．ここで，加熱前後の各試料の色および磁性の変化を調べた．色の変化は光学顕微鏡を用いて調 べ, 磁性の変化は磁石を試料に近づけ, 磁石への付着有無によって判定した.

結果を表 5 に示寸. 加熱によってフェノール樹脂は黄色から黒色に变化し, 炭化したことが認められる.また, $\mathrm{Fe}_{2} \mathrm{O}_{3}$ のみの試料では加熱による色・磁性の変化は認められなかった. 一方, フェノール樹脂と $\mathrm{Fe}_{2} \mathrm{O}_{3}$ を混合した 試料では赤色から黒色に変化し, さらに加熱前にはみられなかった磁性が認められた.つまり, 試料に含まれて いた $\mathrm{Fe}_{2} \mathrm{O}_{3}$ が $\mathrm{Fe}_{3} \mathrm{O}_{4}$ に還元されたことがわかる.

以上の結果から，フェノール樹脂が分解する際には金属酸化物を還元する作用をもつことが確認でき，摩擦面 においても還元反応が存在することが示唆される. 著者らは，このように摩擦面でパッド中のフェノール樹脂が 分解し，金属酸化物を還元する機構を摩擦還元と位置つけた。

Table 5 Color and magnetism of test samples before and after the heating test

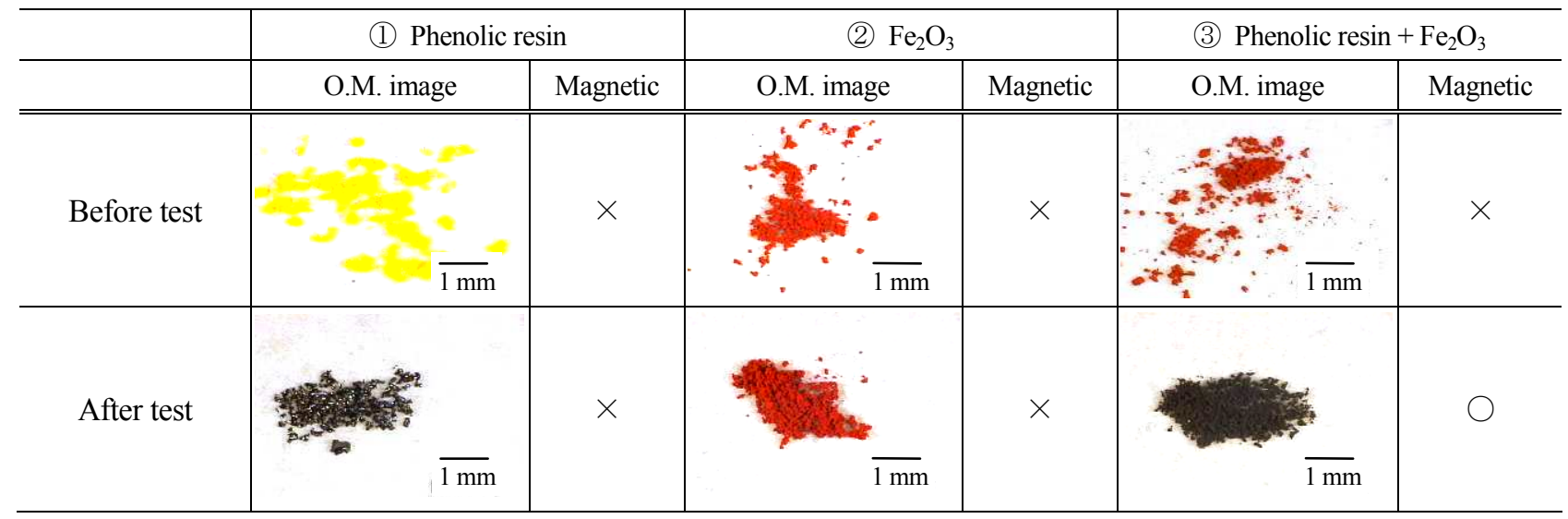

\section{$4 \cdot 3$ パッド材の摩耗に与える金属酸化物の特性}

パッド材の摩耗にはディスク材への被膜層の凝着性が影響することを $4 \cdot 1$ で述べた. また, 凝着性に違いが生 じる要因としてフェノール樹脂の分解による金属酸化物の摩擦還元機構を挙げ， $4 \cdot 2$ で検証を行った. ここでパ

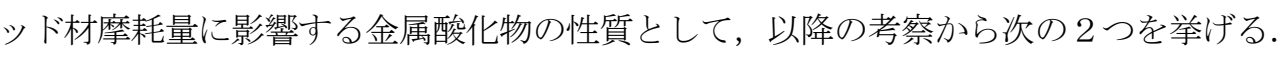


（1）金属酸化物の還元されやすさ

（2）金属酸化物の還元によって生じた金属とディスク材（鋳鉄）との凝着性

まず，金属酸化物の還元されやすさを比較するため，金属酸化物の標準生成自由エネルギー(20)を用い，パッド 材の摩耗量と添加した金属酸化物の性質との関係について考察を行った．標準生成自由エネルギーは反応速度の 予測はできないものの, 化学反応の方向を予測することができ, 標準生成自由エネルギーを用いたエリンガム図 によって金属酸化物の還元されやすさを相対的に評価する報告もみられる ${ }^{(21)}$. すなわち, 標準生成自由エネルギ 一の值が負の方向に大きくなるほど金属酸化物は化学的に安定であり，摩擦時においても還元されにくい金属酸 化物であると考えられる，そこで，本論文では金属酸化物の標準生成自由エネルギーとパッド材の摩耗量との関 係を調べた。

その結果を図 15 に示す, パッド材の摩耗量が少ない $\mathrm{CeO}_{2}, \mathrm{MgO}, \mathrm{TiO}_{2}$ は, 標準生成自由エネルギーの絶対值 が大きく，同時に評価した金属酸化物の中でより還元されにくい金属酸化物であることを示す，一方，パッド材 の摩耗量が多い $\mathrm{SnO}_{2}, \mathrm{Bi}_{2} \mathrm{O}_{3}, \mathrm{CuO}$ は標準生成自由エネルギーの絶対值が小さく, 還元されや寸い金属酸化物で ある.つまり，添加した金属酸化物が還元されにくいほじパッド材の摩耗量が低減されることがわかる．なお，

$\mathrm{Fe}_{2} \mathrm{O}_{3}$ と $\mathrm{Fe}_{3} \mathrm{O}_{4}$ が上記関係を示した図中の直線から外れていることについては, 次のように考察する.

まず， $\mathrm{Fe}_{3} \mathrm{O}_{4}$ についてであるが， $\mathrm{Fe}_{3} \mathrm{O}_{4}$ は還元されるとディスク材と同種金属の $\mathrm{Fe}$ に変化する.つまり，ディ スク材と高い凝着性を示す “ともが敉”の摩擦が生じることになる.この同種金属同士の高い凝着性がパッド材 の摩耗を著しく増大させ，これが $\mathrm{Fe}_{3} \mathrm{O}_{4}$ を添加したパッド材の摩耗量が図中の直線から外れた要因である.

次に, $\mathrm{Fe}_{2} \mathrm{O}_{3}$ について述べる. $\mathrm{Fe}_{2} \mathrm{O}_{3}$ は $\mathrm{Fe}_{3} \mathrm{O}_{4}$ と同様に $\mathrm{Fe}$ の酸化物であるにも関わらず, パッド材の摩耗量が少 ない. これを説明するには，摩擦時に $\mathrm{Fe}_{2} \mathrm{O}_{3}$ は金属にまで還元されていないと推測するのが妥当である。一般に $\mathrm{Fe}_{2} \mathrm{O}_{3}$ が金属まで還元される際には， $\mathrm{Fe}_{3} \mathrm{O}_{4}$ の状態を経る(22)ことが知られている.このことから, 摩擦時にはパッ ド材に添加した $\mathrm{Fe}_{2} \mathrm{O}_{3}$ は金属まで還元されずに, 次の酸化状態, すなわち $\mathrm{Fe}_{3} \mathrm{O}_{4}$ で留まったものと推定される. このように，金属酸化物が金属に還元される際に異なる酸化状態を経る場合には，摩擦時における金属酸化物の 還元されやすさを標準生成自由エネルギーで比較することが難しいと考えられる. これが $\mathrm{Fe}_{2} \mathrm{O}_{3}$ を添加したパッ ド材の摩耗量が少なく，上記関係に従わない理由である.

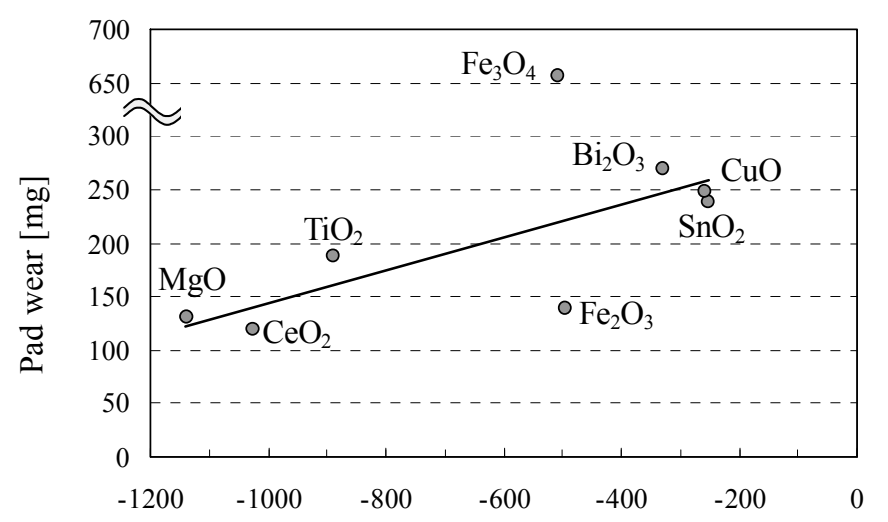

Standard Gibbs free energy of metal oxide formation $[\mathrm{kJ} / \mathrm{mol}]$

Fig. 15 Relationship between pad wear and standard Gibbs free energy of metal oxide formation

\section{5. 結言}

ブレーキパッドの耐摩耗性向上の新たな取り組みとして, サブミクロンから $1 \mu \mathrm{m}$ 程度の微細な金属酸化物を フェノール樹脂複合材であるパッド材に添加し, 摩耗量に対する影響を調查した。 また, 摩擦面および摩耗粉を 分析し，摩耗機構の解明を行った．得られた結論を以下に示す.

(1) 添加する金属酸化物の種類によってパッド材摩耗量は変化し, $\mathrm{CeO}_{2}, \mathrm{MgO}, \mathrm{TiO}_{2}, \mathrm{Fe}_{2} \mathrm{O}_{3}$ を添加した場合に は金属酸化物を添加していないパッド材よりも摩耗量が少なくなり, $\mathrm{Fe}_{3} \mathrm{O}_{4}, \mathrm{SnO}_{2}, \mathrm{Bi}_{2} \mathrm{O}_{3}, \mathrm{CuO}$ を添加した 場合には摩耗量が多くなった。特に， $\mathrm{Fe}_{3} \mathrm{O}_{4}$ を添加した場合には摩耗量が最も多くなった. 
(2) 摩耗量が多くなったパッド材では, パッド材摩擦面に形成される被膜層の組織が粗く, ディスク材への移着 も多くみられた．また，摩耗粉中には粗大な摩耗粉が多いことがわかった。これは，パッド材摩擦面に形成 される被膜層がディスク材と凝着しや寸くなることで被膜層が脱落し, 粗大摩耗粉として系外に排出されや すくなるためである。つまり，ディスク材に対する被膜層の凝着性がパッド材摩耗量に大きく影響する.

（3）添加した金属酸化物によって上記凝着性に違いが生じる理由は, 摩擦面で金属酸化物を還元する機構が存在 するためであり，金属酸化物の還元されや寸さ，および還元によって生成された金属とディスク材との凝着 性がパッド材摩耗量の支配要因と解釈される.

（4）摩擦面で金属酸化物が還元される原因は，パッド材中のフェノール樹脂の分解によると推定した. これは, $\mathrm{Fe}_{2} \mathrm{O}_{3}$ とフェノール樹脂の混合試料を加熱したモデル実験において, $\mathrm{Fe}_{2} \mathrm{O}_{3}$ が $\mathrm{Fe}_{3} \mathrm{O}_{4}$ に還元された結果からも 説明できる．著者らは，このフェノール樹脂の分解が引き起こす摩擦面での金属酸化物の還元反応を摩擦還 元と位置づけた.

\section{文献}

(1) 自動車技術ハンドブック，設計（シャシ）編 (2005), p. 165, 自動車技術会.

(2) 藤川裕之, 田中俊彦, “ブレーキ摩擦材の技術動向と評価法の規格化”, トライボロジスト, Vol. 53, No. 8 (2008), pp. 512-517.

（3）佐々木要助，日下聡, “自動車ブレーキ用材料の変遷”, トライボロジスト, Vol. 48, No. 3 (2003), pp. 197-201.

(4) 奥田敏晴,“ブレーキシステムの技術動向とトライボロジー”トライボロジスト, Vol. 54, No. 9 (2009), pp. 592-597.

(5) Katsuya Okayama, Hiroya Kishimoto, Tatsuhisa Kubota, Ken'ichi Hiratsuka, "A study on the effect of iron oxide $\left(\mathrm{Fe}_{2} \mathrm{O}_{3}\right)$ in a brake pad on pad wear", Proceedings of World Tribology Congress 2009 Kyoto (2009), p. 131.

(6) K. Hiratsuka, K. Muramoto, "Role of wear particles in severe-mild wear transition", Wear, Vol. 259 (2005), pp. 467-476.

(7) H. Kato, K. Komai, "Tribofilm formation and mild wear by tribo-sintering of nanometer-sized oxide particles on rubbing steel surfaces", Wear, Vol. 262 (2007), pp. 36-41.

（8）原泰啓, 萬代慶丙, 両角宏喜, 中西宏之, 鈴木茂生, “ブレーキ用高摩擦係数ディスクパッド”, 日立テクニカルレポ 一ト No.41 (2003), pp. 45-48.

(9) 石井勇樹, 西谷要介, 小久保邦雄, 関口勇, 北野武, “フェノール樹脂系複合材料のトライボロジー特性に及ぼすエ ラストマー添加の影響”, トライボロジー会議予稿集 東京 (2011), pp. 187-188.

(10) 久保亮五, 長倉三郎, 井口洋夫, 江沢洋, 岩波 理化学辞典, 第 4 版 (1987), p. 831, 岩波書店.

(11) 柳田博明, 微粒子工学大系, 第II巻 応用技術 (2002), p. 294, フジ・テクノシステム.

(12) 日本セラミック協会, セラミック工学ハンドブック (1989), pp. 798-816, 技報堂出版.

(13) 牧野和孝, 鉣物資源百科辞典 (1999), pp. 470-807, 日刊工業新聞社.

(14) K. Hiratsuka , T. Yoshida, "The twin-ring tribometer-Characterizing sliding wear of metals excluding the effect of contact configurations", Wear, Vol. 270 (2011), pp. 742-750.

(15) 柳田博明, 微粒子工学大系, 第 I 巻 基本技術 (2002), pp. 132-134, フジ・テクノシステム.

(16) 日本潤滑学会, 潤滑ハンドブック (1987), pp.26-27, 養賢堂.

(17) 井上光弘, 原泰啓, 笹田直, “せん断力によるブレーキ材料用フェノール樹脂硬化物の分解（第 1 報, 抽出物の分子 量分布）”，日本機械学会論文集 C 編, Vol.56, No521 (1990), pp. 222-227.

(18）奥野嘉雄, “鉄鉱石から鉄を生み出寸（中）”, NIPPON STEEL MONTHLY Vol.2004.1·2 (2004), pp. 11-14.

(19) Douglas Godfrey, "Iron Oxides and Rust (Hydrated Iron Oxides) in Tribology", Journal of the Society of Tribologists and Lubrication Engineers (1999), pp. 33-37.

（20）日本化学会, 化学便覽, 基礎編 I, 改訂 3 版 (1984), pp. 306-313, 丸善.

(21) 上村正雄, “グラファイト材料のトライボロジー” , トライボロジスト, Vol. 54, No. 1 (2009), pp. 4-9.

(22) 雀部高雄, 大蔵明光, 江本房利, 吉越英之, 福永弘一, “鉄鉱石の還元について”, 生産研究, Vol. 18, No. 6 (1966), pp. $142-148$. 